\title{
PSYCHICAL DISTANCE \\ IN THE INTERNATIONALISATION PROCESS \\ OF MICRO AND SMALL ENTERPRISES
}

\author{
MAGDALENA BROJAKOWSKA-TRZĄSKA
}

University of Szczecin, Faculty of Management and Economics of Services, POLAND

e-mail: magdalena.brojakowska@wzieu.pl

RECEIVED
ACCEPTED
JEL
CLASSIFICATION

KEYWORDS

ABSTRACT
18 January 2018
2 September 2018

$F 18, F 23, F 29$

psychical distance, internationalization, micro and small enterprises

Despite the development of new technologies and "flattening of the world", psychical distance is a relevant factor in the internationalisation process of micro and small enterprises. This article indicates the importance of psychical distance in the internationalisation process of activities performed by companies of the SME sector, with particular focus put on micro and small enterprises. The multidimensional nature of the concept of distance in the internationalisation process was presented using the CAGE model (cultural, administrative, geographical, economic). The article discusses the concept of psychical distance and stage internationalisation theory in the context of the fundamental Uppsala model. Moreover, the article indicates risk categories of international operations and its impact on the scale of psychical distance in the internationalization of activities.

\section{Introduction}

The internationalisation of company's business activities may be identified as the phenomenon of structural transformation of the world economy. Thanks to the technological progress and and fierce competitiveness, the form of company's activities is changing from simple trade of manufactured goods and services on the local market 
to the internationalisation of all the company's undertakings. This applies to not only big enterprises, but more and more often to micro and small companies as well.

The concept of distance and the related assumptions, stating that location can affect the character of business transactions, constitute the basis of the theory of foreign trade and international undertakings. In the gravity models of international trade, which are built on a macro-scale, the key variable determining the value of trade between two countries is the geographical distance (Ciszewska-Mlinaric, Wasowska, 2012, pp. 3-22). Whereas, the theories concerning internationalisation of companies developed on a micro-scale are based on the assumption that an obstacle to internationalisation is the foreignness of a market where foreign expansion takes place, and the resulting additional costs of doing business abroad (related to e.g. lack of familiarity with the market, language barriers, lack of orientation in the political and legal system).

The aim of the article is to identify the importance of psychical distance in multidimensional typology of distance in the internationalization of a company, as well as its importance in the process of internationalization of micro and small enterprises.

\section{The importance of distance as an obstacle to internationalization}

The importance of distance in the context of limiting internationalization of enterprises and their development on foreign markets can be analysed in two ways.

On the one hand, the development of new forms of transport and communications technology improves international integration process and reduces the significance of distance as a barrier hindering this process. The promotion of the Internet (which disregards location) diminishes the importance of internationalization analysis as a process of "overcoming distance" (Hamill, 1997). Furthermore, there are also "forces" that have an impact on shortening the distance and "flattening of the world", with some of them being:

- the Internet,

- changes in value chain configuration e.g. outsourcing, offshoring, supply-chaining (building a competitive advantage based on a fast and reliable supply chain),

- workflow management technologies.

On the other hand, entrepreneurs tend to overestimate the attractiveness of foreign markets. In this case, the claim that psychical distance is becoming of a lesser importance in internationalization process is premature, especially with regard to micro and small enterprises. Underestimating the role of psychical distance may lead to wrong decisions of entrepreneurs (managers), e.g. the choice of the wrong market, inappropriate way of entering a foreign market, or mismatched development strategy on a foreign market.

It is also worth noting that the CPA analysis, which is based on the level of GDP and inclination for consumption, and which determines absorption capacity of the given market, does not take into consideration the aspects of cultural and administrative distance of market access for a particular company, which are important elements of psychical distance of internationalization.

\section{Multidimensionality of distance in intepnationalization. The concept of psychical distance.}

The first multidimensional typology of distance, known in the literature as the CAGE model, was formulated by Ghemawat (Ghemawat, 2001, pp. 137-147). The name of the model is an acronym of words cultural, administrative, geographic and economic. Berry, Guillen and Zhou (2010, pp. 1460-1680) extended Ghemawat's typology with five 
additional dimensions: financial (the development level of financial markets), political (political stability, democracy level), demographic (demographic structure of society), communication (tourism and access to the Internet) and knowledge-related (patents and level of scientific knowledge). Due to the fact that three of these dimensions can be treated as a more detailed typology of Ghemawat (financial and knowledge-related versus economic; political versus administrative) (Ciszewska-Mlinaric, Wasowska, 2012, p. 6), and the other two (demographic and communication) were only marginally used in empirical works (Berry, Guillen, Zhou, 2010, pp. 1460-1680), four basic distance dimensions are discussed below (Table 1),

Table 1. Multidimensionality of distance in internationalization (a reference to the CAGE model - cultural, administrative, geographical, economic)

\begin{tabular}{|c|c|c|}
\hline Distance dimension & Elements & \multirow{6}{*}{ 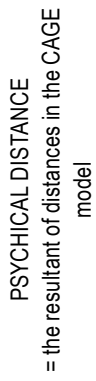 } \\
\hline Cultural distance & different languages, national groups, religions, social norms, lack of trust & \\
\hline cuitural distance & differences in relation to power, individualism and the importance of work and family & \\
\hline Administrative distance & $\begin{array}{l}\text { no participation in the economic community, lack of a single currency, political hostility } \\
\text { differences regarding the regulatory, cognitive and normative area }\end{array}$ & \\
\hline Geographical distance & $\begin{array}{l}\text { distance, no common border, different time zones, climatic differences } \\
\text { the great-circle distance (shortest distance) between geographic centers of countries }\end{array}$ & \\
\hline Economic distance & $\begin{array}{l}\text { differences in the income of residents } \\
\text { differences in costs and quality: natural resources, financial resources, human resources, infrastructure, } \\
\text { intermediate raw materials, knowledge and information } \\
\text { differences in the level of economic development and macroeconomic indicators }\end{array}$ & \\
\hline
\end{tabular}

Source: own work based on: Ciszewska-Mlinaric, Wąsowska (2012).

Psychical distance differs from cultural distance, despite the fact that in many empirical papers these terms are used interchangeably. Psychical distance is the resultant of four distances included in the CAGE model.

Psychical distance, contrary to cultural distance, which concerns differences between countries as understood by managers, regards perception, i.e. phenomena occurring in the mind of an individual person. Therefore, psychical distance should not be subject to operationalization by means of "objective" factors (level of education, language or level of GDP per capita) (Ciszewska-Mlinaric, Wasowska, 2012).

Furthermore, according to the Uppsala school, psychical distance concerns many dimensions of differences between countries, such as language, culture, political system, level of education and the degree of industrial development (Daszkiewicz, 2016, pp. 23-24).

The concept of psychical distance (Figure 1) is closely related to the staged theory of internationalization of enterprises and is the foundation of the Uppsala model (U-Model) (Daszkiewicz, 2016).

This model was developed by Swedish researchers J. Johanson and J.E. Vahlne (1977) with the participation of F. Wiedersheim-Paul, and was based on the observation of behaviour of Swedish enterprises on international markets in the mid-1970s. It could be assumed that the stage model reflects internationalization of micro and small enterprises, which most often start internationalization from ad hoc export, and then develop their activities by "baby steps" (implementing further forms of internationalization in countries with an increasing psychical distance). 


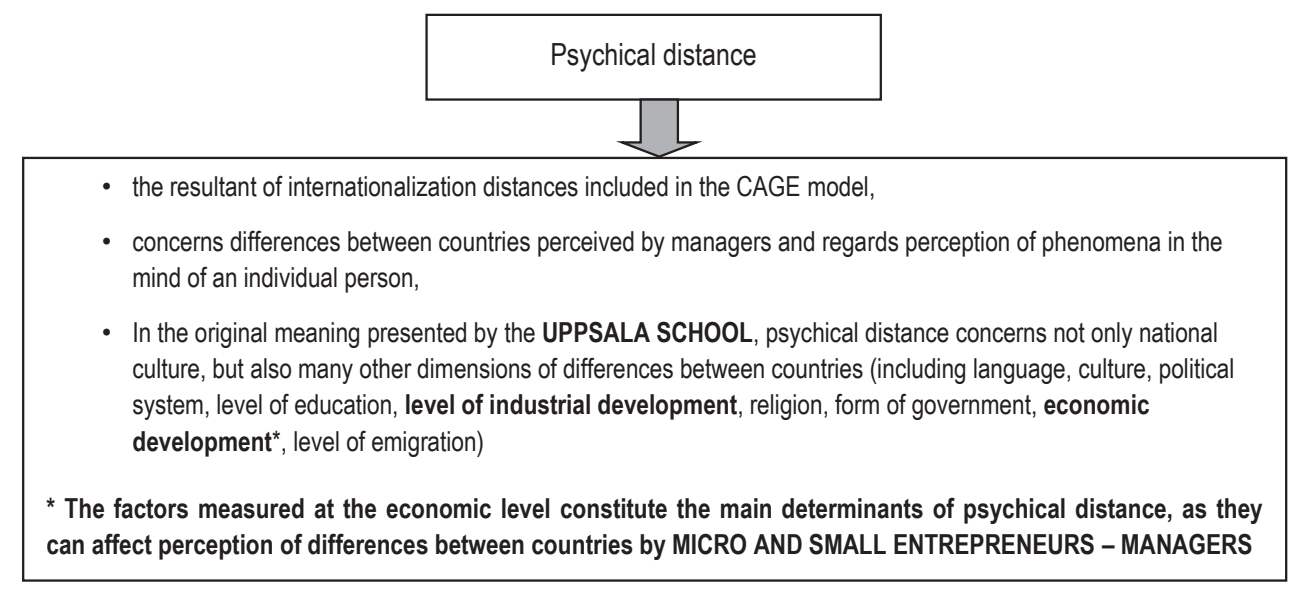

Figure 1. The concept of psychical distance

Source: own work.

The internationalization process in this model is understood as the interaction between the development of knowledge concerning foreign markets and activities, and the growing involvement of resources.

\section{The risk of internationalization}

The level of risk in internationalized activity of an enterprise is incomparably higher than in the case of activity on the domestic market, which results mainly from the greater number of factors affecting the company's operations, which are difficult to recognize and predict.

Depending on the applied form of internationalization and "psychical distance" between the country of origin of the company and the country of planned expansion, the changes in company's organization may be of a different character and intensity. This results in the increase in the risk level concerning the company's activities. Figure 2 presents the types of risk in the internationalization process.

In the case of enterprises operating on foreign markets, it becomes important that manufacturing and financial processes take place most often across borders, which means that economic activity is performed in various countries, and that payment streams related to them are made in different currencies.

Due to the complex correlation of manufacturing and finance processes, financial management in an enterprise operating on the foreign market contributes to the creation of many tasks that are not found in the finances of enterprises operating exclusively on the home market. Reference can be made to e.g. the increased necessity to fund raise (in enterprises operating on international markets there is a greater demand for capital, while at the same time internationalized enterprises have increased access to financial markets), preserving autonomy when making strategic decisions, or risk management in the scope of exchange rates, capital costs and country risk.

The risk of company's international business activity constitutes an uncertainty function that results from the openness of the company and its coexistence in the global environments. In case of micro and small enterprises that operate on a local scale, it is sufficient to recognize chances and threats determined by the micro/sector 
environment and macro environment. Whereas, in the case of internationalization process of business activity started by micro and small enterprises, it is necessary to systematically monitor the global environment.

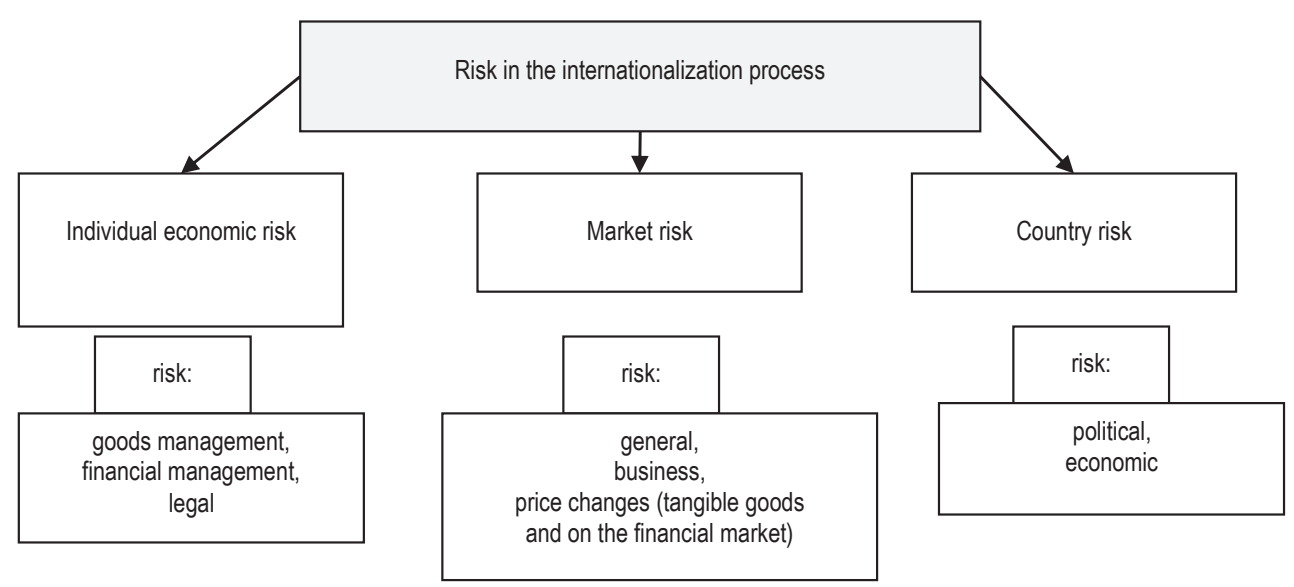

Figure 2. Risk in the internationalization process

Source: own work based on Bielawska (2004).

Micro and smal enterprises

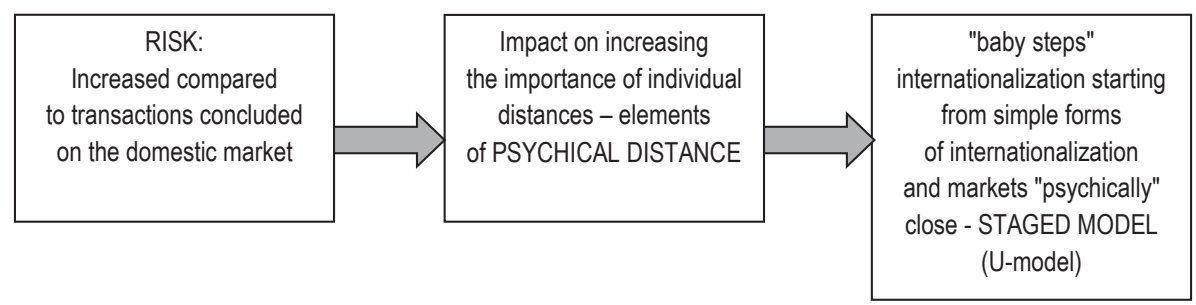

Figure 3. Relation: internationalisation risk - psychical distance - U-model

Source: own work.

The increased internationalization business risk contributes to the increase in individual internationalization distances that are elements of psychical distance, which in turn leads to internationalization of micro and small companies' business activities with the use of simple internationalization tools (e.g. export) and by entering markets with small psychical distance (Figure 3).

\section{Conclusions}

Psychical distance, despite the development of new technologies and "flattening of the world", is of a significant importance in the internationalization process of small enterprises. The distance discussed is multidimensional and 
comprises cultural, administrative, geographical and economic distances. The fundamental element of psychical distance is the distance at an economic level, as it affects the micro and small entrepreneur-managers' perception of differences between countries.

If compared to transactions concluded on the domestic market, the risk in the internationalization process is higher, and thus increases individual internationalization distances constituting the elements of psychical distance. The above-mentioned risk encourages the smallest companies to internationalize their business by taking baby steps using simple forms of internationalization (e.g. export) and entering markets that are psychically close to their home country.

\section{References}

Berry, H., Guillen, M.F., Zhou, N., (2010). An institutional approach to cross-national distance. Journal of International Business Studies, 41 (9), 1460-1680.

Bielawska, A. (2004). Finanse zagraniczne. Kontrakty - rozliczanie płatności - kredytowanie. Szczecin: Wydawnictwo Naukowe Uniwersytetu Szczecińskiego.

Ciszewska-Mlinaric, M., Wąsowska, A. (2012). Znaczenie dystansu w procesie internacjonalizacji przedsiębiorstw. Management and Business Administration. Central Europe, 6 (119), 3-22.

Daszkiewicz, N. (2016). Terytorialny zakres internacjonalizacji polskich przedsiębiorstw: wyniki ankietyzacji. Prace Komisji Geografii Przemysłu Polskiego Towarzystwa Geograficznego, 30 (1), 21-29.

Ghemawat, P. (2001). Distance still matters: The hard reality of global expansion. Harvard Business Review, 79 (8), 137-147.

Hamill, J. (1997). The Internet and International marketing. International Marketing Review, 14 (5), 300-323.

Johanson, J., Vahlne, J.E. (1977). The internationalization process of the firm - a model of knowledge development and increasing foreign market commitments. Journal of Internationalization Business Studies, 8 (1), 23-32.

Cite this article aS: Brojakowska-Trzaska, M. (2018). Psychical distance in the internationalisation process of micro and small enterprises. European Journal of Service Management, 3 (27/2), 43-48. DOI: 10.18276/ejsm.2018.27/2-05. 